\title{
NATIONAL AND SUPRANATIONAL LAW IN THE EEC ON THE EVE OF BRITISH ENTRY
}

\section{P. JoHN KozYRIs*}

The legal aspects of European integration are of interest to the American lawyer both for practical and theoretical reasons. In advising clients who export or operate in Europe, he needs to be aware of at least the main features of the new common legal system, principally regulatory in' nature, which is rapidly expanding in the EEC and of the inter-relationship between it and the national legal systems. If he is serving the government or an international organization in a capacity touching upon international trade, he is required to acquire an even deeper understanding of how this new system of law functions. The prospective enlargement of the EEC, engulfing especially the United Kingdom, a traditional base of American operations in Europe, underscores the practical utility of knowing more about the EEC. Furthermore, the prospect of the United States participating with Europe in a broader Atlantic Community is not as remote as it used to be and the EEC integration experience can provide a valuable model for a broader organization.

On the theoretical level, the EEC is probably the most intriguing and innovative legal creation of recent times. Admittedly the imperfect offspring of a compromise between federative ideals and nationalist realities, it defies classification. Its legal system is neither international nor municipal, neither confederate nor federal in nature, but a little bit of each. In other words, it is sui generis, to the despair of the taxonomists and to the detriment of its logical consistency and cohesion. This elusiveness of characterization can be understood and accepted, however, when one realizes that the EEC is but a step in the direction of a gradual, continuous process of integration which is gathering momentum and becoming increasingly irreversible. ${ }^{1}$

\section{The Rome Treaty: Between Treaty and Constitution}

It is not within the scope of my presentation to go into the details of the arguments over the precise nature of this hermaphrodite, conceived under the sign of Hermes, the God of Commerce, but I will explain briefly why the Rome Treaty is more than a traditional international agreement and less than a federal constitution. ${ }^{2}$ Law.

* Visiting Professor of Law, Duke Law School. Professor of Law, Ohio State University College of

The present article is a slightly expanded version of an address to the Institute on the Expansion of the Common Market held at the Duke Law School on April 14-15, 1972, under the auspices of the Law School and the A.B.A. Section on Comparative and International Law. The bibliographical references are limited to the more recent publications and authorities in this field.

${ }^{1}$ P. Hay, Federalism and Surranational Organizations 40-4I (ig66).

2 The legal system of the EEC is discussed in HAY, supra note 1, at 42-1or; Sasse, The Common 
The Rome Treaty is more than a treaty for a number of reasons.

First, many of its provisions are directly applicable within the member states, creating rights and obligatons in private persons to be recognized and enforced by national courts irrespective of municipal law. They are thus more than selfexecuting treaty-type provisions. ${ }^{3}$

Second, and most important, the Rome Treaty has set up independent supranational institutions which are endowed with extensive original legislative, executive, and judicial powers. This has been interpreted as involving the transfer of some sovereign powers ${ }^{4}$ and not merely the delegation of authority coupled with the assumption of obligations by independent states. ${ }^{5}$ The Treaty and the norms created by these institutions, which often are also directly applicable within the member states, constitute a new legal order separate from, and in fact superior to, the national legal systems.

Third, the scope of powers placed in supranational hands, even though limited to trade and economic matters, is far broader than that of any comparable international organization. ${ }^{8}$

Fourth, the institutional structure of the EEC is such that no member state is in a position to block the exercise of such powers in most instances.

And fifth, the negotiations leading to the Treaty, the text of the Treaty itself, and the subsequent actions and pronouncements of the member states demonstrate an intent to move toward a more closely knit community of peoples rather than an alliance of states. ${ }^{7}$ As a result, the Treaty is not being interpreted strictly, under the traditional rules applicable to treaties, but rather expansively, with a view to giving full effect to its objectives.

On the other hand, the Rome Treaty falls short of being a federal constitution.

To begin with, the supranational powers of the EEC relate only to trade and economic matters. The constitutional and political structures of the member states remain' intact and their governments retain considerable freedom in the conduct of foreign relations and of internal, non-economic affairs. In a sense, it is as if the United States

Market: Between International and Municipal Law, 75 YALE L.J. 695 (I966); A. Green, PoLITICAL INTEGRATION BY JURISPRUDENCE I-37, 4I4-33, 463-90 (I969).

${ }^{3}$ See Bebr, Directly Applicable Provisions of Community Law: The Development of a Community Concept, Ig INT'L \& COMr. L.Q. 257-6I (I970).

- See text accompanying notes 45-52, infra.

' See Korowicz, Some Present Aspects of Sovereignty in International Law, I02 ACADEMIE DE DRoIT International, Recueil des Cours (I) r,I08 (xg6r).

The German Zollverein and the Danube Commission, which were created in the second half of the nineteenth century, possessed very limited powers and functioned essentially on a technical level. See HAY, supra note $\mathrm{I}$, at $4-5,29$.

TOn recent progress in this area, see Note, The European Communities-The Perspective of European Integration, 42 Current Notes on INT'L AfFarRs 43, 47-48 (197r); Jacqué \& Knaub, Le Parlement Eutopéen, 7 Revue Trimestrielle de Droit Européen [Rev. Trim. Dr. Eur.] 714, 715-I7 (I97I). The views of the Commission are summarized in its Opinion on the Applications for Membership of the United Kingdom, Ireland, Denmark and Norway which appears in English translation as CCH Comm. MKT. REP., Supp. 124, at I-8, 34-35 (1970). France is reported to insist that the new European "political secretariat" be located in Paris while some of the other states, including England as a prospective member, would prefer Brussels. N.Y. Times, March 20, 1972, at I, col. 8. 
Government were vested with only the commerce power. The Rome Treaty contains very little, if anything, that pertains to the system of government of the states and to the fundamental rights of the people. It must be noted here, however, that ail member states but France are parties to the European Convention for the Protection of Human Rights and Fundamental Freedoms, prepared under the auspices of the Council of Europe, which goes a long way in guaranteein'g individual rights. ${ }^{8}$ Even in the economic sphere, the Treaty does not adequately provide for full economic and monetary union and it is understood that it will be revised accordingly in the next few years, assuming a continuing consensus of the states.

The people of the member states have not participated in any direct way in the preparation of the Rome Treaty and in its continued application. The adoption procedure used was that for a normal treaty and no attempt was made to give it constitutional force internally. Furthermore, it is amendable again only as a treaty and the people have no direct power to shape its future content. ${ }^{10}$ There does exist a European Assembly, commonly referred to as the Parliament, which consists of appointed members from the state legislatures, ${ }^{11}$ but it is essentially an advisory and deliberative body without real powers other than, in an exceptional case, to force resignation of the EEC Commission by a two-thirds vote. ${ }^{12}$ While the Treaty calls for the eventual direct election of the members of the European Parliament ${ }^{13}$ and the Parliament has already made a proposal to the EEC Council to that effect, ${ }^{14}$ the Council has not yet acted; and its unanimous consent to the change is required. ${ }^{15}$

Another significant difference between the Rome Treaty and a constitution is that the EEC is not given direct authority to tax or to raise armies or maintain a police force. The purse and the sword have been zealously kept in the hands of the member states. Some progress has been made, however, in the financing of the EEC budget. During the transitional period, the EEC depended on contributions

\footnotetext{
${ }^{8} 213$ U.N.T.S. 22x, registered August II, I955.

${ }^{\circ}$ On the problems of proceeding with monetary and economic union, and on the recent progress made in dealing with them, see Maas, The Powers of the European Community and the Achicvement of the Economic and Monetary Union, 9 CoMm. MKr. L. REv. 2 (1972); Everling, Institutional Aspects of a European Economic and Monetary Union, 8 CoMM. MKT. L. REv. 495 (I97x); Carreau, La Communaute Economique Europécne Face aux Problémes Monétaires, 7 Rev. TriM. Dr. Eur. 586 (1971); 2 CCH COMM. MKt. Rep. If 9358, 9406 (1970), 9415 (197I). For the text of the Werner Plan, see 7 Rrv. TrIm. DR. EUR. 687 (197I). On the revitalization of the drive toward such a union, following the currency crisis of late $197 \mathrm{I}$, see Press Release of The European Community Information Service, March 29, 1972, reproduced in 2 CCH CoMm. Mrr. Rep. I9502 (1972); Wall St. J., March 8, 1972, at 6, col. 2. The Council has already started a practice of issuing annual reports on the economic situation in the Community and establishing detailed guidelines on action to be taken. For the first such report, see 2 CCH COMM. MKT. REP. I 9468 (I97I).

${ }^{10}$ Treaty establishing the European Economic Community, March 25, 1957, I CCH CoMm. MkT. Rep. I5449, 298 U.N.T.S. I4-94 [hereinafter cited as Rome Treaty], art. 236.

${ }_{11}$ Rome Treaty, art. 138 ( 1 ).

${ }^{22}$ Rome Treaty, art. 144 .

${ }^{18}$ Rome Treaty, art 138 (3).

14 I CCH COMM. MkT. REP. I 4306 (Ig67).

${ }^{15}$ Rome Treaty, art. $138(3)$.
} 
from the member states and on a portion of the agriculture levies..$^{16}$ Under the new system which became effective in I97I, the EEC has its own resources consisting of (i) all agricultural levies, and eventually all customs duties, collected at the EEC borders, less a ro\% collection charge; (ii) state contributions; and (iii) beginning with 1975 , a percentage of up to one point of the value-added tax of the states. ${ }^{17}$ Incidentally, most of the EEC's resources, which are approaching two billion dollars annually, are expended in support of the agricultural program. ${ }^{18}$

Turning to the EEC institutions, it is obvious that they do not constitute a complete federal government. The Commission, embodiment of the federative ideal and guardian of the Treaty, is independent of the states on a long term basis ${ }^{10}$ and is entrusted with a complex of executive, administrative, legislative, and quasijudicial powers. The reach of such powers, however, is rather short because all important decisions are to be made by the EEC Council of Ministers. The Commission is thus largely a technocratic institution and the fact that it is not accountable to any elected body was used by the Gaullists, in an almost derisive manner, to downgrade it in seeking to limit its authority. ${ }^{20}$ The EEC Council of Ministers, which holds supreme power in the Community, is made up of ministers currently in office, one from each member state. ${ }^{21}$ While the Council is an EEC organ having powers of its own, and not merely an intergovernmental conference, it inevitably reflects the views of the governments of the states rather than of the Community as a whole. The major decisions of the Council of Ministers require unanimity ${ }^{22}$ and most others, a weighted supermajority. ${ }^{23}$ Consequently, the Council is particularly vulnerable to centrifugal and sectional pressures. It was in this crucial forum that France almost was able to paralyze community progress in the mid-

\footnotetext{
${ }^{10}$ Rome Treaty, art. 200. See Sertoli, The Structure and Financial Activities of the European Regional Communities, 26 LaW \& Contemp. Pros. 515, 529 (I96I). See also infra note 17.

${ }^{17}$ Rome Treaty, art. 20r. See I CCH CoMn. MKr. ReP. I5012 (197I); Great Britain, The UNITED Kingdom and the European Communimes Cmnd. No. 47x5, at 23-24, 4x-42 (r97I).

${ }^{18}$ The common agricultural policy, which is based on a price support system, is discussed in Olmi, Common Organisation of Agricultural Markets at the Stage of the Single Market, 5 CoMM. MKT. L. REv. 359 (r968); Megret, La Politique Agricole Commune, 7 Rev. Trim. Dr. Eur. 457 (1971); Megret, Les Développements de la Politique Agricole Commune depuis le ler Janvier 197o, 7 Rev. Trim. Dr. Eur. 745 (197r). The price support system has not been working very well, resulting in high prices to the consumer, exorbitant profits to the owners of large farms and big surpluses. The Council of Ministers recently adopted guidelines aimed at improving agricultural structures, encouraging the withdrawal of labor from cultivation of the land, and providing some minimum support to the small farmers. See Press Release from the Council of the European Communities, No. 608/72, Brussels, March 24, 1972, reproduced in $2 \mathrm{CCH}$ CoNM. MRT. REP. I 9503 (r972);N.Y. Times, March 20, 1972, at 59, col. 7; Wall St. J., January 3I, 1972, at 20, col. 2.

${ }^{10}$ Treaty Establishing a Single Council and a Single Commission of the European Communities effective July $x$, 1967, art. Io-II, I CCH: COMM. MKT. REP. II 5115, 5126-67, Journal officies des CoMMUNAUTÉS EUROPÉENES, July 13 , 1967, at $152 / 5-152 / 6$.

${ }^{20}$ See H. Steiner \& D. Vagts, Transnational Legal Problems im69-7I (i968).

21 The Treaty Establishing a Single Council and a Single Commission of the European Communities effective July I, 1967, art. 2, I CCH COMM. MKT. REP. II 5115, 5II8, JourNal OFFiciel des CoMMUNAUTÉs EUROPÉENNES, July 13,1967 , at $152 / 4$.

${ }^{22}$ See, e.g., Rome Treaty, arts. 50, 100, 149, 223(3), $235 \& 238$.

${ }^{28}$ See, e.g., Rome Treaty, arts. 43(2), 54(2), 75(I), 92(3)(d), Ior, Ir3(4) \& II4.
} 
I960's. ${ }^{24}$ Since then the EEC has made enormous progress, but France has attached what amounts to a unilateral reservation to the Rome Treaty to the effect that all decisions of the Council that affect important national interests must be taken unanimously. ${ }^{25}$ This important issue is presently unresolved, ${ }^{26}$ and if France manages to have its way in the future, consistent with the Gaullist latter-day view of the EEC as a confederation of independent, sovereign states, then' the crucial step would not have been taken and the point of no return toward federalization would not have been reached.

The Court of Justice of the European Communities is probably the most federal of the EEC institutions in that it has supreme jurisdiction and authority to interpret and, in some instances, apply the Community law. ${ }^{27}$ At the same time, there is an important gap in its jurisdiction. Private parties claiming violation of Community law by the member states have no direct right to appeal or even petition for certiorari to the Court of Justice. Instead, they must depend on the willingness of the national courts to refer community law issues to the European' Court. ${ }^{28}$ There is also a hole in the Court's authority in that, in article 177 reference cases, the Court may not rule directly on the compatibility of national law with Community law. The most it can do is to interpret or to pass upon the validity of Community law in the abstract.

\footnotetext{
${ }^{24}$ From July of 1965 through January of 1966 , France had no representative on the Council, demonstrating its unhappiness over lack of progress in the agricultural sector and expressing its reservations about the exercise of supranational powers by the institutions of the Community. In many respects, the more significant work of the Community institutions was suspended during this period. See H. STEINER \& D. VaGts, sispra note 20, at II69; E. Stein \& P. Hay, Law and Institutions in the Atlantic Anea ro6-ro (rg67).

${ }^{25}$ The crisis of 1965 ended in the so-called Luxembourg Compromise. The pertinent language of this Compromise reads as follows:

" $x$. In the event of decisions that can be adopted by majority on the proposal of the Commission, when very important interests of one or several partners are at stake, the members of the Council will attempt, within a reasonable period of time, to arrive at solutions that could be adopted by all members of the Council in respect of their mutual interests and those of the Community in accordance with Article 2 of the Treaty.

2. With regard to the preceding paragraph, the French delegation considers that, when very important interests are concerned, discussion must be continued until unanimous agreement has been reached.

3. The six delegations acknowledge that a difference of opinion remains on what should be done in the event that conciliation cannot be fully attained."

Reproduced in E. STEIN \& P. HAY, supra note 24 , at III-I2. See also H. STEINER \& D. VAGTs, stipra note 20, at II7I-13; Lambert, The Constitutional Crisis 1965-66, 4 J. Comm. MkT. STud. 195 (I966).

${ }^{26}$ It is particularly disappointing to find an approving reference to this de facto unanimity requirement in the British White Paper of I97I (supra note I7, at 8). The extent to which the British are committed to this position is not clear. It has been reported that during the Pompidou-Heath talks of March, 1972, the British were in favor of strong and energetic Community institutions and broad Community powers. N.Y. Times, March 20, r972, $\$ \mathrm{x}$, at $\mathrm{x}$, col. 8.

${ }^{27}$ Rome Treaty, arts. $164-88$. For a study of the role of the Court of Justice through a detailed analysis of its case law, see A. GreEN, supra note 2.

${ }^{28}$ Rome Treaty, art. 177. See Mashaw, Ensuring the Observance of Law in the Interpretation and Application of the EEC Treaty: The Role and Functioning of the Renvoi d' Interpretation tunder Article 177, 7 COMM. MKr. L. REv. 258, 262, 265 (1970); Hay, Supremacy of Community Law in National Cotrts, I6 AM. J. CoMp. L. 524, 530-3I (1968).
} 
It is then incumbent upon the national courts to refuse to enforce national law if it conflicts with Community law. ${ }^{29}$

With respect to the enforcement of Community law, the impotence of the Community institutions is even clearer. There is no Community enforcement machinery, and it is only through an obligation imposed on the states that Community law is expected to be put into effect. ${ }^{30}$ Even in the extreme situation where the Court of Justice finds a Treaty violation by a member state in proceedings instituted by the Commission or another member state, ${ }^{31}$ compliance with the decision is left to the good grace of the offending state. ${ }^{32}$ No supremacy clause is included in the Treaty which formally invalidates conflicting state legislation; there are no specific sanctions imposable under the Treaty for state violations even of an economic, let alone military, nature; and there are no explicit provisions against withdrawal. Hence, it is possible for a state to disengage itself from the Community, subject only to whatever consequences may be incurred under the international law of treaties. $^{33}$ It must be pointed out, however, that as a practical matter, the closer and larger the Community, and the more comprehensive the package of benefits and obligations associated with it, the more difficult it would be for a state to return to a condition of isolation. The economic and political price of withdrawal would be prohibitive. It is noteworthy that despite the misgivings of some governments, especially that of France, about the supranational expansionism of the EEC institutions, no member state defied the Community to the end. The flexibility shown by EEC institutions in' taking into account the special problems of the member states is to be credited in part for this record of compliance. The French Conseil d' Etat probably came close to evading its obligations under the Treaty by persistently failing to refer Community law issues to the Court of Justice as required by article I77, either by focusing on the national law aspects of the particular case ${ }^{34}$ or by relying on the "acte clair" doctrine. ${ }^{35}$ but it finally came through with a referral,

\footnotetext{
${ }^{20}$ See Mashaw, supra note 28, at 266-70; Hay, supra note 28, at 539-43; Buxbaum, Article 177 of the Rome Treaty as a Federalizing Device, 2 I Stan. L. Rev. I04I, 104 n.I9 (I969).

${ }^{30}$ See Rome Treaty, art. 5.

${ }^{31}$ Rome Treaty, arts. 169-70.

${ }^{32}$ Rome Treaty, art. I7r.

${ }^{33}$ But see Rome Treaty, art. 240, which provides that the Treaty "is concluded for an unlimited period," which would imply the absence of the right of unilateral denunciation. See also the conclusions of an Advocate General of the European Court in [Court Decisions 196I-I966 Transfer Binder] $\mathrm{CCH}$ Comm. MKr. Rep. $\{8023$ ( 1964$)$. It is to be noted that Rome Treaty, art. 219, requires that all disputes concerning the interpretation or application of the Treaty should be resolved through the methods provided for in the treaty.

${ }^{34}$ See, e.g., Syndicat général des fabricants de semoules de France, [1968] D.S. Jur. 285 (Conseil d' Etat); Hay, supra note 28, at 549-50. For cases in the French Cour de Cassation and other courts, see Buxbaum, stupra note 29 , at 1045, n. I9. For further discussion of this point, see Hay, supra note $I$, at 134-35; Mashaw, supra note 28, at 430-34.

${ }^{35}$ See, e.g., Re Societé des Petroles Shell-Berre, 84:2 Gazette du Palait 35 (Conseil d' Etat), 3 Comm. Mrr. L. Rev. 462 ( 1964 ). For other such cases of the Conseil d'Etat, see Hay, supra note 28 , at 533 , n. 52. For a discussion of the meaning and implications of this doctrine, see Hay, sutpra note 28, at 532-35; P. HAx, stupra note I, at 136-38. Mashaw, supra note 28, at 278-85; Buxbaum, supra note 29 , at r045-46; Chevallier, Note on Soc. des Petroles Shell-Berre, 3 Comm. Mrr. L. Rev. r00, 105-57 (1965).
} 
to the relief of all concerned. ${ }^{36}$

\section{II}

\section{Community Law and National Law}

With this introduction, we turn to the main topic: the source, form, and content of Community law and its relation to national law at the present stage of evolution of the Europeanization process.

As was indicated earlier, the legislative function of the EEC is shared by two institutions: the Commission and, for more important matters, the Council of Ministers. Quite often these institutions must act together, with the Commission proposing and the Council approving. What kind of legal rules may be put into effect? A look at article 189 shows that these institutions may adopt regulations and directives, make decisions, and formulate recommendations and opinions.

The so-called regulation is the principal form of legislation in' the Community. It is of general and direct application within the states. A directive, on the other hand, binds the states to which it is addressed only as to the result to be achieved but leaves the means to them. Directives are generally used to produce desired legislative ends but are not drafted in the form of statutes. Decisions bin'd directly the addressees, be they states or private parties, and they are mostly in the nature of administrative rather than legislative acts, especially when addressed to private parties. Recommendations and opinions have no binding force.

Probably the most debated issue in Community law has been the extent to which acts other than regulations are directly applicable within the member states. ${ }^{87}$ While it is recognized that the Treaty provisions themselves often, and that regulations almost invariably, are directly applicable and have a direct internal effect, the question. whether directives and decisions addressed to the states can have a direct internal effect had not received a uniform answer until recent decisions of the Court of Justice disposed of this issue in the affirmative. In three cases decided in late 1970, Grad, $^{38}$ Lesage, $^{39}$ and Haselhurst, ${ }^{40}$ the Court held that a Council decision pro-

\footnotetext{
According to a former French Advocate General of the Court of Justice, the Conscil d' Etat has been acting reasonably under Article I77, and both the "acte clair" doctrine and the "independent national grounds" approach are compatible with the reference procedure, if properly applied. Lagrange, The European Court of Justice and National Courts, 8 CoMm. MkT. L. REv. 313 (1971). See also, Lassalle, L'application de l'art. 177 due traité CEE par le Conseil d' Etat francais, I I RivisTa DI Diritro EUROPEO I92 (I97I).

${ }^{80}$ Syndicat Nat'l du Commerce Extérieur des Céréales v. Office Nat'l Interprofessionnel des Céréales, I6 Recueil de la Jurisprudence de la Cour I233 (Cour de Justice de la Communité Européene I970 [hercinafter cited as Recueil de la Cour], 2 CCH CoMm. MrT. Rep. If 8122 (1970).

${ }^{87}$ For a good review of this issue, see Bebr, supra note 3, at 257 (1970). See also, Brinkhorst, Case Law: Salgoil v. Ministry of Foreign Commerce of Italy, 6 Coмm. MKr. L. Rev. 478 (x969).

${ }^{38} \mathrm{Grad} v$. Finanzamt Traunstein, I6 Recueil de la Cour 825, 2 CCH CoMM. MkT. REP. I8107 (I970).

"Transports Lesage \& Cie v. Hauptzollamt Freiburg, i6 Recueil de la Cour 86r, 2 CCH Coms. Mxt. REP. II 8108 (1970).

40 Haselhorst v. Finanzamt Düsseldorf-Altstadt, I6 Recueil de la Cour 88r, 2 CCH Comm. Mkr. REP. I $8 \mathrm{IOg}$ (1970).
} 
hibiting the cumulation of the value added tax and special taxes in the transportation industry had direct effect within Germany and could be invoked by private parties. In the $S A C E$ case, ${ }^{41}$ decided about the same time, a Council directive addressed to Italy, relating to the prohibition against imposing internal charges having an effect equivalent to customs duties, was again held to have direct effects. The Court appears to use a functional test and does not limit itself to the form of the Community act involved. The decision on direct effect hinges upon whether the act in question, by its nature, context, and wording, imposes clear and unconditional obligations which are capable of creating rights in private parties by reflection. It has been said that this position of the Court, which obviously tends to extend the ambit of Community law as such, shows a dynamic-progressive rather than a historicaltextual interpretation of the Treaty and is bound to accelerate integration. ${ }^{42}$

The Court's expansive interpretation of the substantive provisions of the Treaty, almost as if it were a constitution, is underscored in a 1969 case between France and the EEC Commission. ${ }^{43}$ In that case, France sought the annulment of a Commission decision which prohibited France from maintaining a preferential rediscount rate for commercial paper used to finance export credits. The Commission claimed that this constituted state aid which was prohibited. France charged that the Commission exceeded its authority and acted ultra vires because the preferential export rediscount rate, and the general rate to which it was closely connected, came within the realm of France's monetary policy and balance of payments decision-making, which were not within the coverage of the Treaty. The Court rejected the French contention, pointing out that the powers vested in the EEC to coordinate economic policies and to treat exchange policies as a matter of common interest would be frustrated if the states were entirely free, under the pretext that their action related solely to monetary policy, to deviate from the Treaty obligations.

This case appears to support the view that the Community and its institutions possess such implied powers as are necessary and proper in order to give effect to the Treaty provisions. ${ }^{44}$ This is quite important in the interpretation of article 235 of the Treaty which provides that "if any action by the Community appears necessary to achieve, in the functioning of the Common Market, one of the aims of the Community in cases where this Treaty has not provided for the requisite powers of action, the Council, acting by means of a unanimous vote on a proposal of the Commission and after the Assembly has been consulted, shall enact the appropriate provisions." If the existence of implied powers is recognized, as in Commission $v$. France, the use of the cumbersome procedure of article 235 apparently would be

\footnotetext{
${ }^{1}$ S.A.C.E. s.p.a. v. Italian Ministry of Finance, 16 Recueil de la Cour I213, 2 CCH Comm. MkT. REP. $18 \mathrm{Ir} 7$ (r970).

${ }^{43}$ See Brinkhorst, Case Law: S.A.C.E. v. Ministry of Finance of Italy, 8 Comm. MrT. L. REv. 191384 , 386-92 (197I).

is Commission of the Eur. Communities v. France, 15 Recueil de la Cour 523, 2 CCH Comm. MkT. REp. If 8105 (I969). See Brinkhorst \& Verougstraete, Case Law: Commission of the Eur. Communities v. French Republic, 7 Comar. Mrt. L. Rev. 479, 483-89 (1970).

"See P. HAY, stipra note I, at I85-91, E. STEIN \& P. HAY, supra note 24, at 873-75.
} 
required only where new powers beyond the original treaty provisions are to be created to implement the general Treaty objectives.

What is the status of the Rome Treaty and of the secondary direct Community law in the legal systems of the member states? There are a few principles that are beyond dispute. First, it is clear that the Treaty was duly adopted as such in all member states. Second, there is no doubt that Community law emanates only from the EEC and that the Community legal system is distinct from those of the states. But is Community law merely separate and equal, or is it superior and supreme in the case of conflict within national law of any kind?

This question can be viewed from two different perspectives. From the EEC viewpoint, the answer is clear. Despite the absence of a "supremacy clause" in the Treaty, the Court of Justice has held, beginning with the famous early Van Gend \& Loos $^{45}$ and Costa $^{46}$ cases and culminating in the case of Internationale Handelsgesellschaft ${ }^{47}$ of late I970, that valid Community law is separate from and superior to national law at all times and in all circumstanices. ${ }^{48}$ In the latter case, a German enterprise was contesting the validity of Council and Commission regulations which provided for the forfeiture of bonds posted by exporters of agricultural products when the exportation did not take place. One of the claims made by the plaintiff was that such forfeiture was contrary to the German constitutional provision's protecting economic freedom and requiring proportionality. The German Administrative Court was inclined to agree but referred the case to the Court of Justice under article 177 . The European Court held that national constitutional law cannot be used to invalidate Community legislation or to interfere with its effectiveness in the territory of the member states. ${ }^{48}$ The case settles the supremacy argument. The Court went further, however, and affirmed that it will respect the common constitutional traditions of the member states not because of their status as such but because they are part of the general principles of law which the Court must safeguard as the unwritten law of the Community.

\footnotetext{
${ }^{45}$ N.V. Algemene Transport-en Expedite van Gend \& Loos v. Netherlands Fiscal Adm'n, 9 Recueil de

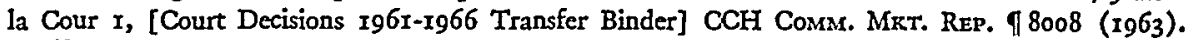

${ }^{40}$ Costa v. Ente Nazionale Energia Elettrica Impresa già della Edison Volta [E.N.E.L.], ro Recueil de la Cour II4I, [Court Decisions I96I-I966 Transfer Binder] CCH. CoMM. MkT. ReP. I 8023 (1964). See, Stein, Toward Supremacy of Treaty-Constitution by Judicial Fiat: On the Margin of the Costa Case, 63 Mírch. L. REv. 49r (x965); Sasse, note 52, infra.

47 Internationale Handelsgesellschaft mbH v. Einfuhr \& Vorratsstelle, I6 Recueil de la Cour II25, 2 CCH COMM. MKT. REP. I 8 126 (1970).

${ }^{\$ 8}$ For a careful analysis of the decided cases up to I966, see Hay, stupra note I, at 153-75.

19 For earlier cases foreshadowing this result, see Stork v. High Authority of the Coal \& Stecl Community, 5 Recueil de la Cour 43 (I959); Enterprise I. Nold K.G. v. High Authority of the Coal \& Stecl Community, 6 Recueil de la Cour 857 ( 1960 ); Sgarlata v. Commission of the EEC, Ir Recueil de la Cour 279 (1965).

${ }^{80}$ This is quite remarkable development, especially in view of the fact that the Rome Treaty makes explicit reference to the "general principles common to the laws of Member States" only in Article $2 x_{5}(2)$ as a source of the rules to govern the noncontractual liability of the Community. On the implications of this aspect of the Internationale Handelsgesellschaft case, and of Stauder $v$. City of Ulm, Sozialamt, I5 Recueil de la Cour 425, [Court Decisions I967-I970 Transfer Binder] CCH CoMm. MKT. REP. १8077 (1969), the only case where this question clearly came up, see Zuleeg, Fundamental Rights and the Law
} 
From the national perspective, however, the domestic court may find itself in a bind when the Community law conflicts with an internal law which is superior to it under the national constitution. The problem arises because no member state adopted the Rome Treaty as a supra-constitutional norm. In all member states, the Treaty has at least the force of ordinary legislation. But what if subsequent internal legislation or another treaty is inconsistent with it and, more importantly, what if the Treaty or secondary Community legislation violates the constitution of a member state? From the EEC viewpoint, it is clear that a state is required to take all measures to eliminate such conflict. ${ }^{51}$ But what should the national judge do? In view of the internal status of the Treaty as such, the national judge has no choice but to follow the hierarchy of the sources of law within his own system. ${ }^{52}$

It is probably in the Netherlands that the Rome Treaty enjoys the highest status. Article 67 of the Dutch Constitution permits the delegation of legislative, administrative, and judicial powers to organizations founded upon the law of nations, and article 66 expressly provides for the superiority of self-executing international agreements over internal legislation. The Dutch judge, who has no authority to review the constitutionality of treaties (article 60 (3) of the Dutch Constitution), would have no difficulty in recognizing the supremacy of Community law and in enforcing it under article 66 of the constitution in case of conflict with any kind of internal legislation. 53 If one interprets these clauses of the Dutch Constitution to authorize irrevocable transfers of powers, then even a subsequent inconsistent treaty would not supersede the Rome Treaty. ${ }^{54}$

In Belgium, the constitutionality of treaties is not reviewable by the courts, but since treaties generally have no greater force than ordinary legislation, under tradi-

of the European Communities, 8 CoMm. MKr. L. REv. 446, 453-6I (I971); Bebr, Law of the European Communities and Municipal Law, 34 MoD. L. REv. 481, 49I-93 (I97I). See also, the written communication on "The Protection of Human Rights in the European Communities" submitted on behalf of the Court of Justice by Judge Pescatore to the Parmliamentary Conference on Human Rights organized by the Council of Europe, reproduced in 9 Comm. MkT. L. REv. 73 (I972). For a more technical discussion of the question of the common general principles, see Lorenz, General Principles of Law: Their Elaboration in the Court of Justice of the European Communities, 13 AM. J. Comp. L. I (1964).

One of the important consequences of the recognition by the Court of Justice of the common constitutional traditions of the member states as a source of the basic law of the Community is that it reduces the possibility that national courts in Germany and Italy might find that the transfer of powers to the Community is contrary to their constitutions which do not permit the violation of fundamental rights in any circumstance. GrundGesetz arts. 19(2), 79(3) (Ger.); ItAlian Const. art. 2. See Zuleeg, stura, at $446-53$.

"See P. HAY, supra note I, at I73.

${ }^{52}$ See Sasse, The Common Market: Between International and Municipal Law, 75 YALE L.J. 695, 7rg (Ig66).

${ }^{63}$ See P. HAY, supra note $\mathrm{I}$, at 27I-72; Sasske, supra note 52, at 705-06; Bebr, supra note 50, at $485-$ 86; E. Stein \& P. HaY, supra note 24, at 54-57. It is interesting to note that a special procedure provided for in article 63 of the Netherlands Constitution, requiring a $\% 3$ majority vote in the legislature for the approval of international agreements which are in conflict with the constitution, was not used for the Rome Treaty, apparently because of the belief that the terms of the treaty were not contrary to the constitution. See Van Panhuys, The Netherlands Constitution and International Law, 58 AM. J. INr't L. 88, 98-99, I06 ( $\left.\mathrm{xg6}_{4}\right)$.

${ }^{\mathrm{S}}$ Cf. P. HAx, supra note $\mathrm{I}$, at $\mathrm{I} 64$. 
tional Belgian practice the Rome Treaty is subject to being superseded by subsequent treaty or statute. ${ }^{55}$ A recent landmark decision of the Supreme Court of Belgium, however, established judicially the supremacy of treaties over municipal law and confirmed the limitation of national sovereignty under the Rome Treaty. In the case of Belgium v. $S$. A. Fromagerie franco-suisse le $S k i$, an' importer of dairy products sued successfully for a refund of customs duties paid under a Belgian law which allegedly was inconsistent with article $\mathrm{i} 2$ of the Rome Treaty. ${ }^{50}$ The Court of Justice had already decided, in an action by the Commission against Belgium, that Belgium had violated article 22 of the Treaty, ${ }_{2}^{57}$ but subsequent Belgian legislation provided that duties already paid were not recoverable. Faced with a conflict between the Treaty and subsequent inconsistent statutes, the Belgian court held first, that the principle lex posterior derogat priori does not apply in this situation because the treaty is not of the same nature as a statute, and second, that a self-executing treaty prevails over inconsistent internal legislation because of the primacy of the international legal order. The court did not stop here, however, but proceeded to hold that the superiority of treaties applies a fortiori to the Rome Treaty which created a new legal order for the benefit of which the member states have limited their sovereignty. This recognition of the limitation of sovereignty could form the basis of a further holding in the future that Belgium no longer has the power unilaterally to adopt measurers of higher status (constitutional amendments or new treaties) contrary to the Rome Treaty. ${ }^{68}$

In Luxembourg, the constitution authorizes the temporary delegation of legislative, judicial, or executive powers to international institutions (article 49-bis) but contains no clause specifically relating to the internal status of treaties. The Luxembourg Supreme Court, however, has generally recognized the superiority of treaties over both prior and subsequent internal statutes, and the constitutionality of treaties is not judicially reviewable. ${ }^{59}$

The French situation is more complicated. Article 55 of the constitution provides that treaties have an authority superior to that of statutes. According to the traditional view, the French practice which strictly prohibits judicial review of the constitutionality of legislation extends to the precedence of treaties over internal legislation. ${ }^{80}$ The modern trend, however, appears to favor judicial consideration

${ }^{{ }^{5}}$ See Sasse, supra note 52, at 7x0-I2; E. STEIN \& P. HAY, supra note 24, at 57-63. A recent amendment of the Belgian Constitution (article 25 bis) provides that "the exercise of power may be conferred by Treaty or by law on institutions of public international law." MoNITEuR BeLge 842x (Aug. 18, 1970). See Louis, L'Article 25 bis de la Constitution Belge, I970 Revoe do Marche Comaru 410.

${ }^{7} 7$ Rev. Trim. Dr. Eur. 494, 2 CCH Coms. MrT. Rep. I 8I4I (r97I) (Cour de Cassation, Iro Chambre, Belg.).

${ }^{27}$ Commission de la EEC v. Luxembourg \& Belgique, ro Recueil de la Cour 1217 (1964).

${ }^{88}$ For a detailed analysis of the issues before the Belgian Supreme Court, see van der Meersch, Suprématie du droit communatuaire sur le droit national, 7 REv. Trum. DR. Eur. 423 (197r) (conclusions of the Attorney General of Belgium).

${ }^{80}$ See Sasse, supra note 52, at 709-10; Bebr, supra note 50, at 486; E. STEIN \& P. HAY, supra note 24, at 63 .

${ }^{00}$ Sasse, supra note 52, at 708-09. 
of the compatibility of a statute with a treaty; ${ }^{61}$ and in a 1970 case, Administration des Contributions Indirectes $v$. Ramel, ${ }^{62}$ the French Cour de Cassation unequivocally refused to apply the French laws relating to quality control and taxation of wines to imported Italian wine which met the Community standards, on the ground that under article 55 of the constitution international law prevails over municipal law in this setting. Since the Community law involved was in the form of regulations and decisions, this case appears to dispel any doubts about whether article 55 applies to secondary Community law and not only to the Treaty itself. ${ }^{63}$

Article 54 of the French Constitution sets up a procedure for preliminary review by the Conseil Constitutionnel, at the request of the President, Prime Minister, or President of an Assembly of the Parliament, of the constitutionality of proposed international commitments. If the Conseil finds that they are in' conflict with the constitution, then they may be ratified only if the constitution is amended. Following the April 2I, I970, Decision of the EEC Council ${ }^{64}$ which established the new system of finan'ing the Community by replacement of state contributions with the Community's own resources, ${ }^{65}$ the EEC members signed a new treaty which increased the budgetary powers of the European Assembly. ${ }^{66}$ There was some political opposition in France to this change, and the argument was made that the new system violated the French Constitution, in particular article 3 which provides that "national sovereignty belongs to the people who shall exercise it through their representatives" and article 34 which requires that all taxation be imposed by law adopted by the Parliament. It was also claimed that the new system was contrary to a traditional principle of French public law that taxes may be imposed only by elected representatives. ${ }^{67}$ In these circumstances, the Prime Minister decided to refer the Treaty and the Council decision to the Conseil Constitutionnel. The Conseil went out of its way to uphold the constitutionality of the treaty and of the Council decision. ${ }^{68}$ It stressed that the Treaty, which was to be ratified as such, only modified the distribution of powers among the organs of the Community and did not affect the balance of relations between the Community and the states. As to the Council decision, which in particular provided for the allocation to the Community of a portion of the value-added tax of the states, the Conseil treated it as merely an implementing measure of the Community treaties which had already been ratified and noted that its enforcement in France was subject to statutory approval under

\footnotetext{
${ }^{61}$ Id. at 709; Hay, supra note 28, at 549-50.

${ }^{22}$ ro ComM. MrT. L.R. 315 (197I). For a comment on this case, see Kovar \& Tallon, infra note 67, at $404-46$.

${ }^{8}$ See Sasse, supra note 52, at 708. See also, note 68 infra.

" For the text of this decision, see 7 Rev. Trim. DR. Eur. 237 (I971).

or See note 17 supra.

${ }^{\circ 6}$ For the text of this treaty, see 7 REv. TrIM. DR. EUR. 242 (197I).

${ }^{\circ}$ See Kovar \& Tallon, The Application of Community Law in France in 1970, 8 ComM. MkT. L. REv. 402-04 (I97I).

${ }^{88}$ For the text of Declaration of the Conseil in French and an English translation, see yo CoMm. MrT. L.R. 70-74 (r97I). On the role of the Conseil Constitutionnel generally, see Waline, The Constitutional Council of the French Republic, I2 AM. J. Comp. L. 483 (1963).
} 
article 53 of the French Constitution, which meant that the requirements of article 34 would be met. Consequently, the Decision did not affect the "essential conditions of national sovereignty." $"$ "

In Germany, the Basic Law expressly provides for the transfer of sovereign powers to international institutions (Grundgesetz article 24). On the other hand, it also contains limitations on the delegation of powers (article 80) and certain fundamental principles are beyond constitutional amendment (article $79(3)$ ). German courts and commentators have generally upheld the validity of the Treaty and recognized the transfer of sovereign powers to the Community, with the result that the Treaty and Community acts are not in principle subject to review under German constitutional law. The only area of uncertainty at this time is whether the Community, in its exercise of the transferred powers, is free from the restraints of the fundamental, unalterable rights guaranteed by the German Basic Law. ${ }^{70}$ The recent acceptance by the Court of Justice of the constitutional traditions of the member states as part of the unwritten law of the Community is bound to make the chances of a conflict in this area much more remote. ${ }^{71}$ While the subordination of subsequent German legislation to Community law is not clearly established, ${ }^{72}$ the indications are that it will be recognized, especially in view of the acceptance of the concepts of transfer of sovereign powers and of the separateness of the Community legal order.

Finally, the relationship between Community and Italian law resembles in many respects the German one. ${ }^{73}$ Article II of the Italian Constitution recognizes the possibility of limitations of sovereignty on condition of equality with other states, albeit less clearly than article 24(I) of the German Basic Law. In the case of Acciaierie San Michele v. High Authority, ${ }^{74}$ the Italian Constitutional Court rejected the contention that certain provisions in the European Coal and Steel Treaty violated articles I02 and II3 of the constitution which require that judicial functions are to be exercised by regularly appointed judges. The ground given was that Community law constitutes a separate and distinct system from national law and is not subject to certain of the restraints imposable under the Italian Constitution. But it would appear that there are limits to the total freedom from such restraints, at least where fundamental rights are concerned. ${ }^{75}$ In Italy, the superiority of Com-

\footnotetext{
${ }^{60}$ For a comment on this case, see Kovar \& Tallon, supra note 67 .

${ }^{70}$ The literature on the relationship between Community and German law is extensive. For discussion in English, see, e.g., A. GreEN, stupra note 2, at 388-406; P. HAY, stipra note $x$, at 273-95; Hay, supra note 28, at 544-48; E. STEIN \& P. HAY, supra note 24, at 37-52, 211-5; Bebr, supra note 50 at 494-96.

${ }^{71}$ See note 50 supra.

${ }^{72}$ Sasse, supra note 52, at 712-13; Hay, stipra note 28, at 547-48; A. GreEN, stcpra note 2, at 396-97.

${ }^{78}$ See A. GreEN, supra note 2, at 348-88; E. Stern \& P. HAY, supra note 24, at 210-11; Hay, supra note 28 , at $543-44$.

${ }^{74} 6$ Coms. Mrt. L.R. I60, 4I Foro Amm. 569 (1965). For comment, see A. Green, supra note 2, at $384-88 ;$ Bebr, supra note 50 , at $496-97$.

${ }^{76}$ See Hay, supra note 28 , at 544; E. STEIN \& P. HAx, stpra note 24 , at 210-11. See also note 50 sipra.
} 
munity law over subsequent internal legislation is also in doubt, ${ }^{76}$ but the rationale of the San Michele case would appear to require it.

The supremacy of Community over national law is further enhanced by the tendency in the Court of Justice to give Community law effect beyond its immediate reach through pre-emption: Four recent cases dealing with customs matters -Bollman, ${ }^{77}$ Waren Import, ${ }^{78}$ Deutsche Bakels, ${ }^{79}$ and Norddeutsches ${ }^{80}$-illustrate this point. For example, in Norddeutsches the Court found that the Community system of import controls relating to frozen beef was comprehensive and complete and that there was no room for supplementation under national law through the imposition of additional guarantee requirements. Otherwise the uniformity of application of the Community system would be jeopardized. States may only take measures to put the Community system into effect.

On the other hand, in the antitrust field the Court found against preemption in the Wilhelm ${ }^{81}$ case, relying in part on the language of articles $87(2)(e)$ and $3(f)$ of the Treaty. At the same time, the Court stressed that the national antitrust laws should not be applied in a way which would be likely to jeopardize the effectiveness of the Community antitrust law. Since the Community antitrust law is directly applicable in the states, presumably the national courts are not permitted to authorize or validate anticompetitive action contrary to Community law even if consistent with the national legislation. In result, this arrangement resembles the American situation.

The impact of Community law upon national law does not end with the directly applicable provisions of the Treaty and secondary Community legislation in such areas as antitrust, customs, transport, and agriculture. ${ }^{82}$. The Treaty envisages harmonization, approximation; or coordination of national laws and policies in the areas already mentioned as well as in all areas related to the creation and functioning of the Common Market.83 This national action is to take place primarily

\footnotetext{
${ }^{70}$ The internal status of the Rome Treaty as ordinary statute was emphasized in the decision of the Italian Constitutional Court in Costa v. Ente nazionale per Energia elettrica impresa già della Edison Volta (E.N.E.L.), Io Recueil de la Cour Ir4I, [Court Decisions 196I-I966 Transfer Binder] CCH Comar. Mrit. REp. If 8023 ( 1964 ). See A. Green, supra note 2, at 348-66.

${ }^{77}$ Hauptzollamt v. Firma Paul G. Bollmann, 16 Recueil de la Cour 69, [Court Decisions r967-197o Transfer Binder] CCH Comm. MkT. ReP. 18098 (I970).

${ }^{78}$ Hauptzollamt v. Waren-Import-Gesellschaft Krohn \& Co., I6 Recueil de la Cour 45I, [Court Decisions r967-1970 Transfer Binder] $\mathrm{CCH}$ CoMm. MRT. ReP. If 8098 (r970).

${ }^{70}$ Deutsche Bakels GmbH v. Oberfinanzdirektion, x6 Recueil de la Cour Ioor, 2 CCH CoMm. MrT. REP. If 8 Ir 8 (r970).

${ }^{80}$ Norddeutsches Vieh-und Fleishkontor GmbH v. Hauptzollamt, I7 Recueil de Ia Cour 49, $2 \mathrm{CCH}$ CoMm. Mrt. Rep. f 8132 (I97I).

${ }^{81}$ Wilhelm v. Bundeskartellamt, I5 Recueil de la Cour I, [Court Decisions I967-I970 Transfer Binder] CCH Comm. MKt. Rep. 18056 (1969). See, 5 Tex. INT'z L.F. 320 (I969).

${ }^{82}$ For an analysis of the directly applicable Community law, see Bebr, supra note 3, at 257; Rambow, The End of the Transitional Period, 6 CoMm. MkT. L. REv. 434 (1969).

${ }^{83}$ See Stein, Assimilation of National Laws as a Function of Europeán Integration, 58 AM. J. INT'L L. I (1964); Vogelaar, Tax Harmonization in the European Commutity, 7 CoMM. MKT. L. REv. 323 (I970); Van der Burg, The Customs Tariff and Customs Legislation in the European Communities, 7 Comm. Mkt. L. Rev. I84 (1970); Beuve-Mery, Les applications des articles 100, 101 et 102 du traite de
} 
under the supervision and through the exercise of the indirect legislative authority of the Community. It must be noted, however, that most of the national economic legislation which affects the Community is of public or regulatory nature and the traditionally private law domain is not significantly affected.

One should not fail to mention the important role reserved for treaties as instruments of uniformization of national rules in the Community. Article 220 of the Treaty envisages treaties among the member states (a) to provide full national treatment to Community persons; (b) to eliminate double taxation; (c) to insure the mutual recognition of companies and the maintenance of their legal personality where their siege social is transferred and to facilitate interstate corporate mergers; and (d) to simplify the reciprocal recognition and execution of judgments and arbitral awards. As of the present time, two of these treaties have been signed. One is on the Mutual Recognition of Companies and Legal Persons ${ }^{84}$ and another, which is quite comprehensive and resembles a full faith and credit clause, is on Jurisdiction of Courts and the Enforcement of Judgments in Civil and Commercial Matters. ${ }^{85}$ In addition, a treaty creating a single Community patent, on top of the national patents, has been drafted and has a good chance of adoption, ${ }^{86}$ while treaties on the transfer of the siege social without loss of legal personality and on interstate corporate mergers are in preparation. ${ }^{87}$ It was also initially thought that the statute for the creation of a European company, that is, a company formed by domestic companies of different nationality and subject to Community law, would be in the form of a treaty. But in the end the Commission prepared such a statute in the form of a regulation under article 189 and submitted it in 1970 to the Council for approval under article 235, the gap-filling provision of the Treaty which requires unanimous Council action. The statute is presently under consideration by the Council and the Parliament but action is not expected before 1973 at the earliest. ${ }^{88}$

la C.E.E. de r958-70, 6 REv. TRM. DR. EuR. 303-08 (1970); Seidel, The Harmonization of Laws Relating to Pharmaceuticals in the EEC, 6 COMM. MxT. L. REv. 309 (1969); Progress of Right of Establishment in the Community, CCH CoMm. Mrt. Rep. I 9473 (1971). See also E. Stern, HarmonizaTION of EuRopean ConPaNy LAWS 237-3I2 (r97I). For information on some of the directives already adopted, see, e.g., I, 2 CCH CoMM. MKT. REP. III 3323 (rg62), 3345 (Ig63), 3361, 3403 (1965), 3450 (I967), 9449, 9453, 9476 (I97I), 9489 (I972).

$86_{2}$ CCH Conn. MRT. REP. T 6083. See Goldman, The Convention Between the Members of the European Economic Community on the Mutual Recognition of Companies and Legal Persons, 7 Comm. MrT. L. REv. T04-28 (I969). See also E. STEIN, supra note 83, at 394-424.

${ }^{85} 2$ CCH COMM. MKT. REP. 16003 (I968). See Goldman, Utz tratié federateur: La Convention entre les Etats membres de la C.E.E. stur la reconnaissance et l'exécution des décisions en matière civile el commerciale, 7 Rev. TrIM. Dr. Eur. I (I97I); Hay, The Common Market Preliminary Draft Convention on the Recognition and Enforcement of Judgments-Some Considerations of Policy and Interpretation, 16 AM. J. Comp. L. I49 (rg68).

${ }^{88}$ Draft Convention relating to a European Patent for the Common Market, 2 CCH CoMm. MKT. Rep. I575I (I970) (first draft). See van Empel, European Patent Conventions, 9 ComM. Mrt. L. Rev. I3, 27-32 (I972).

${ }^{87} \mathrm{CCH}$ ComM. MRT. REP. II 5252.17 (1967), 9436 (I971). See also E. Stein, Harmonization op EURopean Company Laws 371-94 (I971).

${ }^{88}$ For discussion of the contents and present status of the statute, see Van Ryn, Le projet de statut des sociétés européennes, 7 Rev. Trim. Dr. Eur. 563 (I97I); 2 CCH COMM. Mrx. REp. I 938I (I970). See also, E. STEns, supra note 87 , at 424-83. 
It is also quite significant that in certain areas, especially relating to customs and commercial policy toward third countries, the Treaty envisages that treaties will be entered into by the Community itself with third countries in a manner binding on the member states. ${ }^{89}$ This divestiture of some of the members' external sovereignty in favor of the Community was at the center of controversy in the recent landmark decision of the Court of Justice in an action by the Commission against the Council relating to the common transport policy. ${ }^{90}$ During the negotiations for an extension of the European Road Transport Agreement, a separate treaty not related to the EEC, the Council had discussed and determined the positions to be taken for the Community but left it to the states to conduct the negotiations and conclude the agreement. The Commission complained, claiming that the subject matter of the ERTA fell within the field of application of Council Regulation $543 / 1969^{91}$ implementing the common transport policy and that, therefore, it was the Community, through the Commission, and not the states, that had authority to negotiate.

The Court of Justice rendered a decision of major significance. It upheld the Commission's position that the EEC has exclusive treaty-making powers, not only in the few instances where the Treaty expressly so provides, but also by implication with respect to subject matters on which internal Community rules are in effect. The common transport policy adopted pursuant to article 75 of the Treaty is such a subject. The effect of this decision is to make the external authority of the Community in substance co-extensive with the internal one. ${ }^{92}$ While this case does not go as far as the United States case of Missouri v. Holland ${ }^{93}$ which upheld the authority of the federal government to regulate through treaties matters beyond the reach of the internal federal jurisdiction, it represents a giant step in the direction of federalization. Not only does it extend Community authority to the external sphere, but it also recognizes the possibility that certain sovereign powers were transferred to the Community by implication.

\footnotetext{
${ }^{80}$ Rome Treaty, arts. III(2), II3 \& II4. See generally Feld, The Competences of the European Communities for the Conduct of External Relations, 43 TExAs L. REv. 891 (1965); Bot, Negotiating Community Agreements: Procedure and Practice, 7 Comm. Mrr. L. Rev. 286 (I970); Costonis, The Treaty-Making Power of the European Economic Community: The Perspectives of a Decade, 5 Comm. MKT. L. REv. 42I (Ig68).

${ }^{\circ}$ Commission of the Eur. Communities v. Council of the Eur. Communities, $x_{7}$ Recueil de la Cour 263, $2 \mathrm{CCH}$ CoMm. MKT. REP. I 8I34 (I97 I). This is the first case in Community history where the Commission brought an action against the Council.

${ }^{91}$ Art. 7, Council Reg. No. 543/69, Journal officiel des Communautés europénnnes, March 29, I969, at $\mathrm{L77} / 52$.

${ }^{92}$ For a discussion of the implications of this case, see Collinson, The Foreign Relations Powers of the European Communities: A Comment on Commission v. Council, 23 STAN. L. REv. 956 (r97I); Winter, Annotation on Case 22/70, Re ERTA, 8 CoMM. MkT. L. REv. 550 (I97I); Constantinesco, Note under Commission v. Council, 7 Rev. TrnM. DR. Eur. 796 (1971).

It is to be noted that the Court ultimately decided the case in favor of the Council on a very narrow ground, namely that the negotiations on the ERTA had already commenced before the adoption of Regulation $543 / 69$, with the member states participating on their own, and that allowing them to continue under the Council's mandate was not improper under the circumstances.

${ }^{93} 252$ U.S. 416 (1920). In contrast with the states in the United States, the rationale of this case probably would not apply to the Community situation where the member states retain substantial treatymaking powers. See U.S. CoNsT. art. I, § Io.
} 
The story of European integration in the legal sphere does not end with the EEC. The legal systems of Europe are coming together under influences from other institutions as well: the Council of Europe with its Conventions, ${ }^{04}$ the Rome Institute for the Unification of Private Law, and the Hague Academy. ${ }^{05}$ It should also be noted that certain aspects of conflicts of laws may affect the Community. The Commission held discussions on standardizing the choice of law provisions concerning the free movement of goods, services, capital, and workers. Following these discussions, the Commission drafted and submitted to the Council a proposal for the regulation of conflicts of laws relating to labor contracts, with emphasis on the place where the work is normally performed. ${ }^{96}$

\section{III}

\section{IMPACT OF BRITISH ENTRY}

As the United Kingdom and other countries become members of the Community, the legal methods and consequences of their participation in European integration cannot fail to provide a great deal of fascination. In very general terms, the situation is quite simple. The United Kingdom and the others have signed and are to ratify a Treaty of Accession to the European Communities. ${ }^{97}$ While the new members were able to obtain favorable treatment, mostly for a transitional period, on substantive matters and especially agriculture, it is not an exaggeration to say that they have accepted the legal system of the Communities lock, stock, and barrel and are to be bound according to its rules.

To be sure, there are some special problems with the United Kingdom as with most of the present member states. For example, the doctrine of parliamentary sovereignty is fundamentally incompatible with the concept of the transfer of some sovereign powers to the Communities. Since no Parliament can bind its successor, it is virtually impossible to insure that Community law will not be superseded. internally by subsequent inconsistent legislation. ${ }^{98}$ There is some

\footnotetext{
'See Krueger, The Council of Europe and Unification of Private Law, I6 AM. J. CoMp. L. I27 (I968); Baade, The Council of Europe: Its Activities Relating to Law, 15 AM. J. Comp. L. 639 (1967).

${ }^{\circ 5}$ For information on the work of these and other institutions, see Kearney, Progress Report-International Unification of Private Law, 23 Record oF N.Y.C.B.A. 220 (rg68); Hay, The United States and International Unification of Law, 1965 U. IrL. L.F. 820.

${ }^{98}$ I, 2 CCH COMM. MKT. REP. II 3525.03 (I97I), 9498 (I972). For a general discussion, see Drobnig, Conflict of Laws and the European Economic Community, I5 AM. J. CoMp. L. 204 (I967).

97 Treaty Concerning the Accession of the Kingdom of Denmark, Ireland, the, Kingdom of

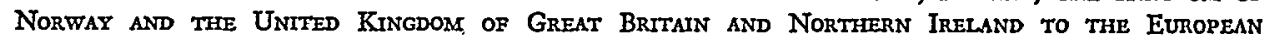
Economic Communtty and the European Atomic Energy Community and Decision of thie Council of the European Communtties Concerning the Accesston of the SAID States to the European ConL AND Steer Congunity, CMND. No. 4862 (r972). In I97I, the British Parliament voted in principle in favor of British entry into the European Communities. In January, 1972, following the signing of the Treaty of Accession, the Parliament approved at first reading the European Communities Bill 1972, reproduced in full in The Times (London), January 27,1972 , at 6 . The debate on the Bill is still continuing at the present time. For some of the argumentation against the Bill, see It's a neat little package, and it explodes when you open it, THE Economst, January 29, 1972, at 29-30.

${ }^{98}$ E. WAde \& G. Philips, Constitumonal Law 44-48 (7th ed. I965); E. STEIN \& P. Hax, supra note 24, at 67; de Smith, The Constitution and the Common Market: A.Tentative Appraisal, 34 Mop.
} 
precedent, developed in connection with the emancipation of the dominions, to the effect that auto-limitations of parliamentary power, supported by usage, may evolve into recognized constitutional practice. ${ }^{99}$ Neither the Accession Treaty nor the European Communities Bill invoke or apparently rely on this practice. As regards prior British law, the European Communities Bill does not rely solely on the principle of lex posterior derogat priori but specifically amends or repeals about fifty existing statutes to make them conform to Community law. ${ }^{100}$ These statutes relate to matters as diverse as restrictive trade practices, companies, motion pictures, customs duties and procedures, coal and steel, food, produce, fertilizers, feeding stuffs, animal health, transport, and agricultural supports and levies.

Another question relates to the direct applicability of subsequent Community law in the United Kingdom. The European Communities Bill is drafted to include such law prospectively even though there is no precedent to support this procedure. $^{101}$ It is likely, however, that it will be upheld, ${ }^{102}$ as it is likely that the Parliament will avoid legislating in conflict with the Treaty. ${ }^{103}$

The consequences of British entry into the Communities for the legal systems of both are bound to be considerable but not overwhelming. Community economic law will be introduced into the United Kingdom with the consequence, for example, that

L. REv. 597, 6rI-I2 (I97I); Martin, The Accession of the United Kingdom to the European Communities: Jurisdictional Problems, 6 CoMm. MkT. L. Rev. 7, 22-23 (1969); Mitchell, "What Do You Want to Be Inscrutable For, Marcia?", 5 CoMm. MkT. L. Rev. II2, Ir6-20 (I968). Mitchell has expressed doubts as to whether the doctrine of Parliamentary sovereignity exists, at least in the form traditionally assumed. See Mitchell, L'Adhesion du Royaume-Uni Aux Communautés, I97o CArIERs de Droit Européen [CAH. Dr. EUR.] 25I, 254-65.

${ }^{00}$ E. STEIN \& P. HAY, supra note 24, at 69; de Smith, supra note 98, at 612-r4; Martin, supra note 98, at 23-24; Mitchell, supra note 98, 5 Comm. MKr. L. Rev. II9-20; Mitchell, supra note 98, I970 CAH, Dr. EUR. 255-59.

In an interesting case decided May 10, I97x, by the London Court of Appeal, Blackburn v. Attorney General, 9 Comm. Mkr. L. REv. 94 (1972), a suit by a British subject for a declaration that the United Kingdom may not join the European Communities was dismissed even though the Court recognized that under the Treaty some British sovereign rights would be shared with others. On the possibility of subsequent Parliaments legislating inconsistently with Community law, Lord Denning is reported to have stated that "[i]t was legal theory that one Parliament could not bind another and that no Act was irreversible; but legal theory did not always march alongside political reality. Take the Statute of Westminster. Could anyone imagine that Parliament could or would reverse it or the Acts which had granted independence to the great dominions and territories overseas, and say that we still had some degree of control over them? Most clearly not. Whatever the theory of Parliament not. being able to reverse itself, the matter could only be tested as and when the time came." Id. at 95.

$200 \mathrm{On}$ why this specific amendment and repeal procedure is" necessary under British law, see Martin, supra tote 98 , at $20-21$.

101 European Communities Bill I972, pt. I, $\$ 2(1)$, supra note 97.

${ }^{102}$ Martin, stipra note 98 , at I7-I8. LEGal and Constitutional IMPLications of UNited Kingdom Memgerseip of the European Communtties, Cmnd. No. 330r, at 8 ( 1967 ).

An interesting question is whether subsequent Community law would prevail over Acts of Parliament adopted after enactment of the European Communities Bill but before the adoption of the Community law in question. The answer is probably in the affirmative on a delegation theory. See de Smith, supra note 98, at 6I0-II; Martin, supra note 98, at I7; Mitchell, supra note 98,-5 CoMM. MKT. L. REv. II7

${ }^{103}$ Mitchell, supra note 98, at 5 Comm. MKT. L. REV. II8; Martin, supra note 98, at 22-23; E. STEIN \&: P. Hax, supra note 24 ," at 68. Furthermore, the British judges will make every effort to interpret away inconsistencies between subsequent Acts of Parliament and Community law. Martin, supra note 98 , at 25-26. 
the British will no longer be able to call their wine "wine" because it is not usually made from fresh grapes but from grape concentrates. ${ }^{104}$ More seriously, the Community antitrust laws will come into effect, which will not produce monumental changes in present practices; ${ }^{105}$ the customs barriers will be abolished; the valueadded tax will be shortly introduced as was planned anyway; ${ }^{\mathbf{1 0 6}}$ and British agriculture will come under the common agricultural policy, leading to higher prices for the consumer and a reduction in deficiency supports for the farmer. ${ }^{107}$

Probably the greatest impact of the Community upon the British legal system will be in the realm of judicial review and administrative law. The courts in England do not pass upon the validity of legislative enactments but they will be required to do so when a question under Community law arises. ${ }^{108}$ The scope of review of the validity of Community administrative action is also broader than that for national action. ${ }^{108}$ Thus, in interpreting and applying Community law the British courts will be functioning as Community courts following, on the whole, continental concepts. ${ }^{110}$ This judicial review will be subject to the ultimate control of the Court of Justice under article 177 , but only on questions of law and only in so far as validity and interpretation of Community law and acts are concerned. The British legal profession will also have to become accustomed to the continental type procedures used at the Community level in judicial and administrative matters and, hopefully, will also exercise some influence on them.

\section{CoNCLUSTON}

Perhaps the most significant aspect of British entry from the legal point of view will be in corporate, tax, labor, transport, conflicts and other matters affecting the functioning of the Common Market, and in the procedural and administrative fields where common law and the civil law concepts will finally be brought together. While the limited amalgamation of these two different systems may delay the process of coalescence, it is bound to provide a stimulus for comparative studies and the end result may be quite impressive. From the American vantage point, the expected infusion of common law concepts and procedures into the Community legal system may be considered as paving the way for an eventually closer, direct relationship between Europe and America. In view of the present realities of world trade, the bridging of the Atlantic, with the possible inclusion of other developed countries, is not a utopian dream. Rather than relying on the traditional system consisting

\footnotetext{
${ }^{106}$ For the Community Regulations on wine, see I CCH CoMm. MKT. REP. If 613-17 (1962-1970).

${ }^{105}$ See Walker-Smith \& Gombos, Restrictive Practices and Monopolies: A Comparison of British and Common Market Law, 3 VA. J. INT'L L. I (1963).

${ }^{208}$ Great Britain, Parliamentary Papers, supra note 17, at 34 .

${ }^{207}$ For a description of the Community agricultural system, see references in note 18 strpra.

108 See E. STEIN \& P. HAY, supra note 24 , at 64 .

102 See de Smith, supra note 98 , at 602; Martin, stpra note 98 , at $45-46$.

120 See Martin, supra note 98, at I4, 29-3I; Mitchell, supra note 98, 5 Cosom. MkT. L. REv. 120-24; E. Stein \& P. Hay, supra note 24, at 67; Conservative Polttical Center, Europe and the Law 80-8I (Ig68).
} 
essentially of intergovernmental organization and cooperation, the Americans and the Europeans may be sufficiently encouraged by the success of the process of gradual economic intergration in Europe to consider using it as a model for the establishment of a true Atlantic Economic Community. On the legal plane, such a development would require constitutional changes in the United States; ${ }^{111}$ and it is time for legal scholars and practitioners and experts in other fields, such as political science and economics, to begin giving serious consideration to the particular problems that would arise and to the adjustments that would be required in such an eventuality.

\footnotetext{
${ }^{111}$ Under present constitutional practice in the United States, the validity of a treaty delegating legislative, judicial and executive powers to a supranational authority and especially empowering such authority to adopt rules and make decisions enforceable in the United States, but placed beyond judicial review under the U.S. Constitution, is subject to serious doubt. See P. HAY, stupra note I, at 205-70; Hay, Cooley \& Moorhead, Problems of United States Participation in the European Common Market, 23 U. PrTr. L. REv. 595 (rg62).
} 